\title{
Changes in chemical composition of germinated leguminous under abiotic stress conditions
}

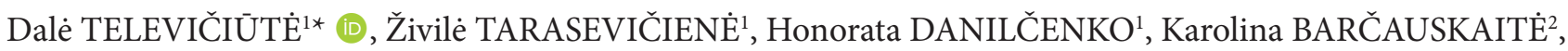 \\ Mantvile KANDARAITE ${ }^{1}$, Aurelija PAULAUSKIENE ${ }^{1}$
}

\begin{abstract}
The aim of this study was to evaluate the impact of abiotic stress conditions on the synthesis of compounds with antioxidant properties in germinating seeds. The seeds of edible lentils (Lens culinaris L.), alfalfa (Medicago sativa L.), and mung beans (Vigna radiata L.) were germinated for 120 hours. We studied the influence of abiotic stress on the amount of dry matter, vitamin $\mathrm{C}$ and phenolic compounds, as well as flavonoids, in germinated seeds. The use of higher than optimal germination temperatures led to a higher accumulation of dry matter in the mung bean, while the accumulation of phenolic compounds and flavonoids was higher in the alfalfa sprouted seeds. Oxidative stress substantially increased the content of dry matter in the seeds of mung bean, and more vitamin $\mathrm{C}$ was found in the lentils. The conditions of abiotic stress in lentil seeds during their sprouting reduced the amount of phenolic compounds in comparison to that in the control variant of the seeds. However, these same conditions (with the exception of oxidative stress) benefitted the accumulation of phenolic compounds in alfalfa seeds.
\end{abstract}

Keywords: sprouted seeds; temperature stress; osmotic stress; oxidative stress; phenolic compounds; flavonoids.

Practical Application: The influences of the abiotic stress conditions on the synthesis of compounds with antioxidant properties in germinating seeds. The study of germinated leguminous under abiotic stress conditions, is necessary because this studies give support for sprouting in the period physiological optimum with maximum value nutrients and enabling the development of new food products.

\section{Introduction}

Plant-based foods are a good source of nutrients, dietary fibre, minerals and phenolic compounds. Legumes, particulary, beans contain bioactive components like phenolic compounds (flavonoids, tannins, and anthocyanin), protease inhibitors, phytic acid, and saponins. Çakir et al. (2019) clarify the potantial of legume plants for human nutrition because of their remarkable molecular content, health benefits, nutritional value and distinctive genomic features. An excellent alternative to plant foods are sprouts, which can be consumed in fresh form at all times of the year. Edible seeds and sprouts are a good source of antioxidants, such as phenolic acids, flavonoids, trace elements and vitamins (Paśko et al., 2009). Germination starts when the dry seed begins to take up water and is completed when the embryonic axis elongates. At this point, reserves within the storage tissues of the seed are mobilized to support seedling growth. From the moment the seed breaks from dormancy, protective responses emerge through the synthesis of phenolics and other compounds (Gharachorloo et al., 2012). Some of the reserve materials of the seeds are degraded and used partly for respiration and partly for synthesis of new cell constituents of the developing embryo during germination; therefore, this process causes important changes in the biochemical, nutritional and sensory characteristics of legumes (Vidal-Valverde et al., 2002).
Bioactive compounds are essential compounds or not which are naturally present in foods and which have several beneficial properties for health, mainly related to their antioxidant power (Silva et al., 2018). Polyphenols display important functions, like inhibition of pathogens and decay microorganisms, anti-deposition of triglycerides, anti-inflammatory and anti-allergic effect through processes involving reactive oxygen species (Graf et al., 2005). Legumes contain several phenolic compounds, which are considered to be natural antioxidants, representing an important group of bioactive compounds in foods, and may prevent the development of many diseases, such as atherosclerosis and cancer (López-Amorós et al., 2006). The presence of phenolic compounds in food has in recent years come to be viewed in a positive light by both scientists and consumers and has resulted in a push to procure food with specific beneficial effects, such as functional foods. After germination, various changes in the phenolic compounds occurred that were not only dependent on the type of seed but also on the process conditions, the presence of light and germination time. Changes in the biochemical content of germinated legumes can be induced by stresses. In plants, phytochemicals are induced in response to biotic and abiotic stresses, acting as natural phytoalexins to protect plants against these stresses (Pérez-Balibrea et al., 2008). Abiotic stresses, such as drought, salinity, extreme temperatures, chemical 
toxicity and oxidative stress are serious threats to plant growth (Khayatnezhad et al., 2010).

It is known that temperature affects the seed germination rate and efficiency of germination. The optimum seed germination temperature depends on their genetic nature. Optimum germination temperature is also related to the ecology of the specific location. The optimum temperature is the temperature that results in the highest germination percentage within the shortest duration of time and can affect the percentage and rate of germination though its effect on the release from dormancy and the germination process itself. Temperature is also a fundamental abiotic stress that can affect plant growth. Low temperature can restrain many kinds of physiological activities in plants, including germination, growth, and metabolic activities (Tripathi et al., 2012).

Salinity is one of the major physical parameters of an environment, which affects almost every aspect of physiology and biochemistry of plants (Złotek et al., 2015). Salt stress is reported to cause decline in seed germination, root and shoot lengths, fresh mass and seedling vigour (Promila \& Kumar, 2000).

Recently, hydrogen peroxide $\left(\mathrm{H}_{2} \mathrm{O}_{2}\right)$ has been regarded as a signalling molecule and regulator of the expression of some genes in cells. Hydrogen peroxide $\left(\mathrm{H}_{2} \mathrm{O}_{2}\right)$ is one of the main chemicals which are elevated in plants by biotic and abiotic stresses. There is an increasing amount of evidence showing that due to its biological activity, $\mathrm{H}_{2} \mathrm{O}_{2}$ serves as a stress signal molecule in plants (Mendoza-Sánchez et al., 2016). $\mathrm{H}_{2} \mathrm{O}_{2}$ is more stable than other ROSs. It readily diffuses across cell membranes and is often used as a model to test the vulnerability of plants to oxidative stress (Quan et al., 2008).

Lim et al. (2012) investigated the effect of salinity stress on phenolic compounds and carotenoids in buckwheat (Fagopyrum esculentum M.) sprout. The results indicated that the total content of phenolic compounds in the control sprouts $(0 \mathrm{mM} \mathrm{NaCl})$ increased with growth time; however, the content at $7 \mathrm{~d}$ of cultivation decreased compared to that at $7 \mathrm{~d}$ of cultivation. The amount of phenolic compounds in the NaCl-treated sprouts increased in a concentration-dependent manner (10-100 mM) over 7 days, at which time the level of phenolic compounds in sprouts treated with 10,50 , and $100 \mathrm{mM}$ was $57 \%, 121 \%$, and $153 \%$ higher than the control sprouts (128 mg of GAE/g, DW), respectively. Other analyses of the total content of phenolics in soybean roots demonstrated that the examined stresses (regardless of their duration) induced accumulation of phenolic compounds. These results are consistent with reports from other studies (Cheynier et al., 2012; Wróbel et al., 2005). It is worth noting that once the germinating seeds were transferred to optimal conditions, the total content of phenolics in roots declined, which suggests return to metabolic balance (Swigonska et al., 2014).

Flavonoids, secondary metabolites, are distributed in the plant kingdom as flavones, flavanols and condensed tannins. These are produced in response to different biotic and abiotic stress factors (Mierziak et al., 2014). López-Amorós et al. (2006) found that seed germination changes the quantitative and qualitative composition of phenolic and flavonoid compounds of bean seeds, and changes depend on the type of plant and germination conditions. The content of flavonoids decreased due to application of $\mathrm{NaCl}$ and $\mathrm{H}_{2} \mathrm{O}_{2}$ as stressors, but an increase was observed when elevated temperature was used. Some researchers have suggested that salt stress creates in plants ionic and osmotic stress resulting in an accumulation or decrease of some secondary metabolites in plants - the effect depends, to some extent, on the sensitivity of the plant to this type of stress condition (Ramakrishna \& Ravishankar, 2011; Mahajan \& Tuteja, 2005).

The aim of this work was to study the effect of abiotic stress on the content of biologically active compounds in legume seeds.

\section{Materials and methods}

The research was carried out over the period of 20162017 at the Faculty of Agronomy, Vytautas Magnus University, Lithuania. One hundred grams of lentil (Lens culinaris L.), alfalfa (Medicago sativa L.) and mung bean (Vigna radiata L.) seeds were germinated in three replications. In the experiment, seeds were germinated in the Bionatura germinator (Poland).

Seeds were germinated for 120 hours at $22^{\circ} \mathrm{C}$ in the dark. Before the experiment, seeds were cleaned to remove any impurities, washed and soaked for 12 hours in water (seeds: water ration, 1:4). After soaking, the water was drained and seeds were spread on the tray of the germinator.

Seeds were periodically irrigated with distilled water every 12 hours. After 48 hours of germination, seeds were subjected to abiotic stress conditions:

- control (no stress);

- temperature stress - for 2 hours the seeds were stored at $35^{\circ} \mathrm{C} ; 40^{\circ} \mathrm{C} ; 45^{\circ} \mathrm{C}$ temperature;

- osmotic stress - for 24 hours the seeds were irrigated with $50 \mathrm{mM} ; 100 \mathrm{mM}$; $150 \mathrm{mM} \mathrm{NaCl}$ solution;

- oxidative stress - for 24 hours the seeds were irrigated with $100 \mathrm{mM} ; 150 \mathrm{mM} ; 200 \mathrm{mM} \mathrm{H}_{2} \mathrm{O}_{2}$ solution.

After 120 hours of germination, the seeds were harvested and samples were taken for analysis. In fresh seeds, mass was determined, along with the amount of dry matter and ascorbic acid. For determination of total phenolic acids and total flavonoids, lyophilized seeds were used.

Ascorbic acid/AA content was determined by titrimetric method using 2,6-dichlorophenolindophenol (Lithuanian Standards Board, 2000).

Content of total phenolics. The method taken from Singleton et al. (1999) was applied for the determination of total phenolics, using Folin-Ciocalteu reagent. The amount of total phenolics was calculated as a gallic acid equivalent (GAE) in $\mathrm{mg} \mathrm{g}^{-1}$.

Content of flavonoids. The flavonoid content of the samples were estimated using the method described by Zhishen et al. (1999). The amount of total flavonoid was calculated as a quercetin equivalent (RE) grams of raw materials and results is presented in $\mathrm{mg} \mathrm{g}^{-1}$.

The results were subjected to a one-way analysis of variance, and the least significant difference (LSD) using Fisher's test at a 
significance level of $p<0.05$ was calculated. Statistical analysis was performed using software STATISTICA 10.

\section{Results and discussion}

The dry matter varies according to the type of seed and germination conditions: temperature, light (dark), moisture and irrigation solutions. Zieliński et al. (2006) indicates that the loss of dry matter in the production of seeds results from their swelling and oxidation of compounds during the respiration process.

The content of dry matter is presented in Table 1. A solution of $50,150 \mathrm{mM} \mathrm{NaCl}$ caused osmotic stress in germinated seeds, increasing the amount of dry matter in the mung beans and alfalfa seeds. Osmotic stress did not influence the content of dry matter in lentils seeds.

After two days of germination and 2 hours at $40{ }^{\circ} \mathrm{C}$, the dry matter content increased substantially compared to the control variant in the mung beans. However, when the temperature increased to 45 degrees, the dry matter decreased from 28.6 to $22.4 \%$. In lentils sprouted for food, the dry matter content at $35{ }^{\circ} \mathrm{C}$ and at $45^{\circ} \mathrm{C}$ was very similar. Temperature stress in alfalfa seeds substantially increased the dry matter content at $45^{\circ} \mathrm{C}$.

Hydrogen peroxide as an inducer of oxidative stress did not influence dry matter content in alfalfa seeds, but significantly reduced dry matter content in lentil seeds. After using $100 \mathrm{mM}$ hydrogen peroxide for seeding the moisture content of the seeds, the amount of dry matter in the mung beans increased by 30 percent.

A lot of data are available concerning the loss of dry matter by seeding seeds of various plant species. Dry matter is lost due to seed soaking and various physiological processes when seeds are germinated. The main factors that determine this are absorption and intensified respiration in the seeds (Ashraf \& Foolad, 2005).
Ascorbic acid is an important metabolite involved in many cellular processes, including cell division (Asard et al., 2003). During germination several enzyme systems become active and bring about profound changes in the nutritive value of pulses. Vitamin C, which is practically absent in dry legume seeds, increases in significant amounts after sprouting (Shah et al., 2011).

When osmotic stress was induced, the vitamin C content increased substantially in mung bean and lentil seeds germinated for food (Table 2). The vitamin C content of alfalfa seeds was mainly influenced by a solution of $100 \mathrm{mM} \mathrm{NaCl}$, and correspondingly vitamin $\mathrm{C}$ content increased by $2.3 \%$.

Vitamin $\mathrm{C}$ had a tendency to increase in mung bean and alfalfa seeds when the seeds were exposed to temperature stress at different temperatures. At 40 and $45^{\circ} \mathrm{C}$, the content of vitamin $\mathrm{C}$ was found to be 6.9 and 1.2 percent higher, respectively, than that in seeds not exposed to stress (control). Temperature stress did not influence vitamin $\mathrm{C}$ content in germinated lentil seeds.

In the sprouted lentil seeds germinated for food, where stress was induced using a solution of $\mathrm{H}_{2} \mathrm{O}_{2} 150$ concentration, the essential amount of vitamin $\mathrm{C}$ was accumulated $(16.7 \mathrm{mg} 100 \mathrm{~g}$ ). However, the $200 \mathrm{mM}$ concentration significantly reduced the amount of vitamin $\mathrm{C}$. The amount of vitamin $\mathrm{C}$ in the mung beans exposed to oxidative stress increased from 2.9 to $10.2 \mathrm{mg}$ per $100 \mathrm{~g}$ and in alfalfa seeds from 3.2 to $4.7 \mathrm{mg}$ per $100 \mathrm{~g}$.

Чупахина (1997) found that darkness could stimulate vitamin $\mathrm{C}$ formation. Other scientists also associate the process of germination with an increase in vitamin C.

The effect of abiotic stress on the amount of total phenolic compounds in legume seeds sprouted for food is shown in Figure 1.

Essentially, the largest accumulation of phenolic compounds was observed in alfalfa seeds exposed to temperature stress $\left(40^{\circ} \mathrm{C}\right)$. Additionally, alfalfa seeds differed from the other seeds, because at all stages of abiotic stress (and control variants), alfalfa seeds showed a significant increase in the amount of phenolic compounds. On the other hand, the smallest amount of phenolic

Table 1. Amount of dry matter in germinated seeds (\%).

\begin{tabular}{|c|c|c|c|c|c|c|c|c|c|c|}
\hline \multirow{3}{*}{ Species of seeds } & \multicolumn{10}{|c|}{ Abiotic stress } \\
\hline & \multirow{2}{*}{$\begin{array}{c}\text { control } \\
\left(\mathrm{H}_{2} \mathrm{O}\right)\end{array}$} & \multicolumn{3}{|c|}{ Osmotic stress $\mathrm{NaCl} \mathrm{mM}$} & \multicolumn{3}{|c|}{ Temperature stress ${ }^{\circ} \mathrm{C}$} & \multicolumn{3}{|c|}{ Oxidative stress $\mathrm{H}_{2} \mathrm{O}_{2} \mathrm{mM}$} \\
\hline & & 50 & 100 & 150 & 35 & 40 & 45 & 100 & 150 & 200 \\
\hline Lens culinaris & $24.35 \mathrm{~h}$ & 22.75 defg & $23.65 \mathrm{fgh}$ & 23.30 defg & $22.25 \mathrm{def}$ & $24.70 \mathrm{~h}$ & $22.55 \mathrm{defg}$ & $21.35 \mathrm{~d}$ & 23.30 defg & $22.70 \mathrm{defg}$ \\
\hline Vigna radiata & $22.80 \mathrm{efg}$ & $29.30 \mathrm{jk}$ & 23.35 defg & $28.45 \mathrm{ij}$ & $23.75 \mathrm{gh}$ & $28.60 \mathrm{ijk}$ & 22.35 defg & $29.90 \mathrm{k}$ & $27.75 \mathrm{i}$ & $30.00 \mathrm{k}$ \\
\hline Medicago sativa & $8.80 \mathrm{abc}$ & $9.80 \mathrm{c}$ & $8.53 \mathrm{abc}$ & $8.10 \mathrm{ab}$ & $8.77 \mathrm{abc}$ & $8.50 \mathrm{abc}$ & $9.73 \mathrm{c}$ & $9.00 \mathrm{bc}$ & $7.37 \mathrm{a}$ & $7.50 \mathrm{a}$ \\
\hline
\end{tabular}

The difference between the variations averages not marked with the same letter (a, b, c, d, e, f, g, h, i, j, k) are significant differences $(P \leq 0.05)$.

Table 2. Amount of vitamin C mg $100 \mathrm{~g}^{-1}$ fresh matter (FM) in germinated seeds.

\begin{tabular}{|c|c|c|c|c|c|c|c|c|c|c|}
\hline \multirow{3}{*}{ Species of seeds } & \multicolumn{10}{|c|}{ Abiotic stress } \\
\hline & \multirow{2}{*}{$\begin{array}{c}\text { control } \\
\left(\mathrm{H}_{2} \mathrm{O}\right)\end{array}$} & \multicolumn{3}{|c|}{ Osmotic stress $\mathrm{NaCl} \mathrm{mM}$} & \multicolumn{3}{|c|}{ Temperature stress ${ }^{\circ} \mathrm{C}$} & \multicolumn{3}{|c|}{ Oxidative stress $\mathrm{H}_{2} \mathrm{O}_{2} \mathrm{mM}$} \\
\hline & & 50 & 100 & 150 & 35 & 40 & 45 & 100 & 150 & 200 \\
\hline Vigna radiata & $3.21 \mathrm{ab}$ & $2.92 \mathrm{~g}$ & $7.86 \mathrm{~g}$ & $2.04 \mathrm{j}$ & $2.05 \mathrm{ef}$ & $4.38 \mathrm{ij}$ & $4.39 \mathrm{gh}$ & $3.75 \mathrm{~g}$ & $4.37 \mathrm{hi}$ & $4.66 \mathrm{ij}$ \\
\hline Medicago sativa & $3.21 \mathrm{~b}$ & $2.92 \mathrm{ab}$ & $5.54 \mathrm{de}$ & $2.04 \mathrm{a}$ & $2.05 \mathrm{a}$ & $4.38 \mathrm{c}$ & $4.39 c$ & $3.75 \mathrm{bc}$ & $4.37 \mathrm{c}$ & $4.66 \mathrm{~cd}$ \\
\hline
\end{tabular}

The difference between the variations averages not marked with the same letter (a, b, c, d, e, f, g, h, I, j, k, l, m, n) are significant differences $(P \leq 0.05)$. 

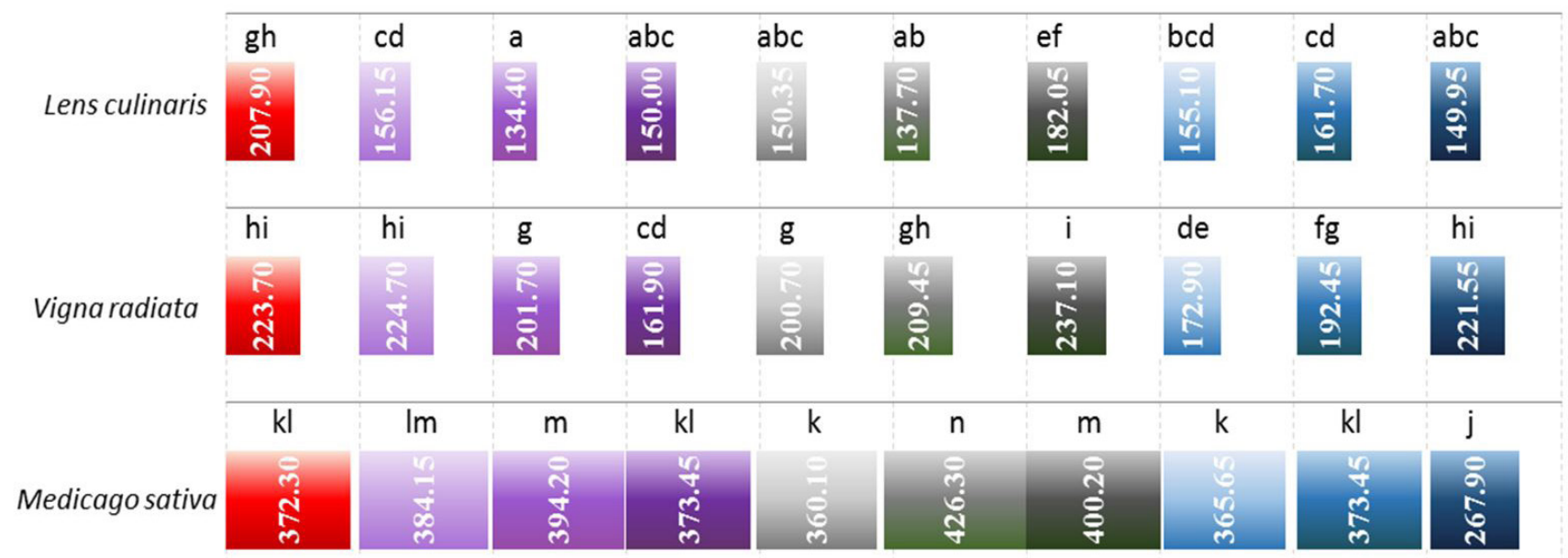

$\mathrm{NaCl} 50=\mathrm{NaCl} 100=\mathrm{NaCl} 150=35^{\circ} \mathrm{C}=40{ }^{\circ} \mathrm{C}=45^{\circ} \mathrm{C}=\mathrm{H} 2 \mathrm{O} 2100=\mathrm{H} 2 \mathrm{O} 2150=\mathrm{H} 2 \mathrm{O} 2200$

\section{Control Osmotic stress $\mathrm{mM} \quad$ Temperature stress ${ }^{\circ} \mathrm{C} \quad$ Oxidative stress $\mathrm{mM}$}

Figure 1. The amount of total phenolic compounds $\mathrm{mg} \mathrm{g}^{-1}$ fresh matter (FM) in germinated seeds. Note. The difference between the variations averages not marked with the same letter $(\mathrm{a}, \mathrm{b}, \mathrm{c}, \mathrm{d}, \mathrm{e}, \mathrm{f}, \mathrm{g}, \mathrm{h}, \mathrm{i}, \mathrm{j}, \mathrm{k}, \mathrm{l})$ are significant differences $(P \leq 0.05)$.

compounds was detected in lentil seeds $\left(1.3 \mathrm{mg} \mathrm{g}^{-1}\right)$ that were exposed to a concentration of $\mathrm{NaCl} 100$.

During osmotic stress, when 100 and $150 \mathrm{mN} \mathrm{NaCl}$ was used, the phenolic compounds in mung beans decreased from 2.2 to $1.6 \mathrm{mg} \mathrm{g}^{-1}$, while phenolic compounds in lentil seeds under 50 and $100 \mathrm{mN} \mathrm{NaCl}$ decreased from 2.1 to $1.3 \mathrm{mg} \mathrm{g}^{-1}$. The content of phenolic compounds did not change in mung beans and alfalfa seeds germinated for food, when exposed to the lowest $\mathrm{NaCl}$ concentration $(50 \mathrm{mM})$.

Temperature stress positively influenced the accumulation of phenolic compounds in mung beans and alfalfa seeds. At $40^{\circ} \mathrm{C}$, stress increased the accumulation of phenolic compounds by $13 \%$ in alfalfa seeds and by $9 \%$ in mung beans.

Oxidative stress did not have a positive effect on the accumulation of phenolic compounds of germinated legume seeds. In sprouted alfalfa seeds, the content of phenolic compounds decreased substantially when the $\mathrm{H}_{2} \mathrm{O}_{2}$ was applied at $200 \mathrm{mM}$.

Under normal conditions, various phenolic compounds are produced during germination. There is much evidence that generation of ROS (reactive oxygen species) during stress in plant induces overproduction of phenolics. These compounds are mainly produced to protect plants from biotic/abiotic stresses such as photooxidation stress, reactive oxygen species, wounds, disease and herbivores (Shulaev et al., 2008)

Flavonoids are among the most bioactive secondary metabolites of plants. Most flavonoids outperform well-known antioxidants, such as ascorbic acid and a-tocopherol (Sarvajeet \& Narendra, 2010). These compounds appear to play vital roles in defence against pathogens and predators and contribute to physiological functions, such as seed maturation and dormancy. At the same time, particular subclasses of flavonoids, such as the proanthocyanidins (condensed tannins), negatively impact the use of seeds and grains in animal feed and can add undesirable qualities to food products for human consumption (Shirley, 1998). Factors such as season, climate, soil composition, maturity stage, preparation, processing, and storage conditions can also directly influence the concentrations of total flavonoids (Kim et al., 2003).

Application of different cultivation conditions (biotic and abiotic stresses) can result in an enhanced production of these antioxidants. These findings were attributed to biochemical changes in sprout metabolism, which might influence the production of compounds, such as anthocyanins and flavonoids, or release aglycones from conjugated glycosides due to enzymatic activation (Shetty, 2004).

Essentially, the highest levels of flavonoids were determined in stress conditions and during germination at $40{ }^{\circ} \mathrm{C}$ for 2 hours in alfalfa seeds, reaching 28.5 and $33 \mathrm{mg} \mathrm{g}^{-1}$, respectively (Figure 2). Essentially, the smallest amount of flavonoids was in the control variant of lentil seeds $\left(2.0 \mathrm{mg} \mathrm{g}^{-1}\right)$.

In alfalfa seeds exposed to different temperatures $\left(35,40,45^{\circ} \mathrm{C}\right)$, the amount of flavonoids increased from 27.2 to $33 \mathrm{mg} \mathrm{g}^{-1}$. When stored at $35^{\circ} \mathrm{C}$, flavonoids in the sprouted lentil seeds increased by 2.4 times, compared with their content in the control lentils. Mung bean seeds demonstrated an increase in the amount of flavonoids at 35 and $40^{\circ} \mathrm{C}$, but a significant decrease in flavonoids at $45^{\circ} \mathrm{C}$, in comparison with that of the control variant seed.

The highest concentration of hydrogen peroxide positively influenced the synthesis of flavonoids in sprouted lentil seeds, but reduced synthesis of flavonoids in the mung bean and alfalfa seeds.

Many flavonoid biosynthetic genes are induced under stress conditions. It has been found that there is a considerable increase in flavonoid levels following biotic and abiotic stresses, such as wounding, drought, metal toxicity and nutrient deprivation 


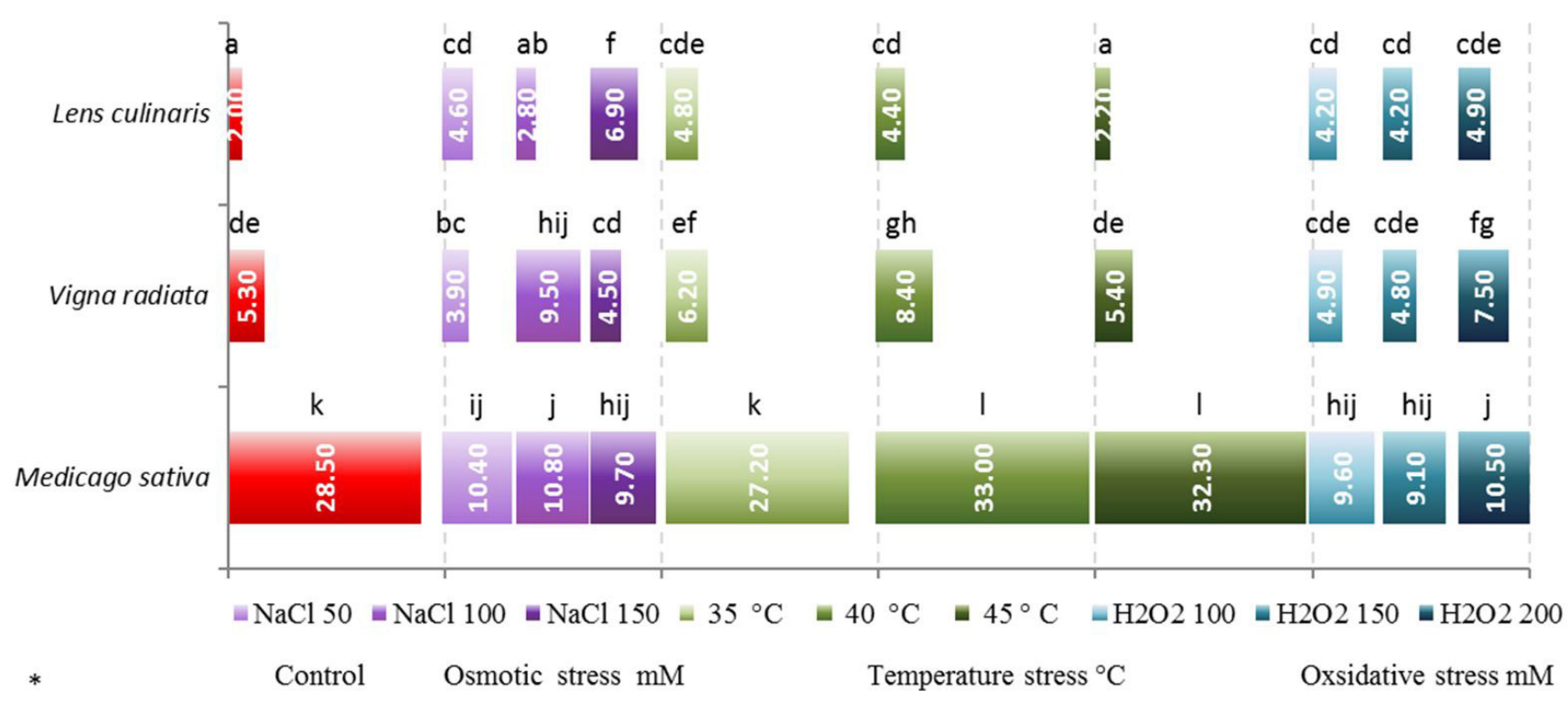

Figure 2. The amount of total flavonoids compounds $\mathrm{mg} \mathrm{g}^{-1}$ fresh matter (FM) in germinated seeds. Note. The difference between the variations averages not marked with the same letter $(\mathrm{a}, \mathrm{b}, \mathrm{c}, \mathrm{d}, \mathrm{e}, \mathrm{f}, \mathrm{g}, \mathrm{h}, \mathrm{i}, \mathrm{j}, \mathrm{k}, \mathrm{l})$ are significant differences $(P \leq 0.05)$. ${ }^{*}$ These authors contributed equally to this work.

(Sarvajeet \& Narendra, 2010). Significant amounts of flavonoids were detected during temperature stress. Physiological processes of plants are largely affected by alterations of the surrounding environmental temperature. An increase in temperature up to a certain level increases plant growth, photosynthesis, respiration and enzyme activity, but if the temperature exceeds this level, these parameters tend to decline. The optimal temperature for structural integrity and activity of most enzymes is within the range of $30-45^{\circ} \mathrm{C}$ (Zróbek-sokolnik, 2012). This temperature has been used to cause stress.

\section{Conclusions}

Germination is a technology that involves physiological changes that improve the digestibility and nutritive value of legumes (Urbano et al., 2005), as well as may be a strategy to increase the content of some bioactive compounds (Fernandez-Orozco et al., 2008; Mbithi et al., 2001). Of all the stresses that were applied to germinated seeds, the most pronounced was temperature stress. Temperature is one of the abiotic factors that can regulate the biosynthesis of phenols. The increase of these compounds could also be associated to a plant mechanism to adapt to temperature regimes, resulting in synergistic biochemical compositions (Tesfay et al., 2016). In general, heat stress affects the stability of proteins, nucleic acids, the cytoskeleton structure and the efficiency of enzymatic reactions, causing a severe metabolic imbalance. The sensing of heat stress takes place at the plasma membrane of cells which is physically altered, acting as a real thermometer (Scholz et al., 2004). The use of a higher than optimal germination temperature of 35 to $45^{\circ} \mathrm{C}$ resulted in a higher content of biologically active compounds (total phenols and flavonoids) in germinated seeds. Seed germination is highly dependent on temperature as temperature is one of the basic requisites of this process. Plants have various enzymatic and non-enzymatic defence systems to minimize the deleterious effects of stress. The increase in temperature up to a certain level increases enzyme activity. According to our research data, the most favourable temperature is $40^{\circ} \mathrm{C}$ (especially for sprouted alfalfa seeds). In fact at that temperature there was a significant increase in biologically active compounds for alfalfa seeds sprouted for food. There are numerous plant studies which indicate the tolerance to temperature stress in plants is positively correlated with an increase in antioxidants (Hasanuzzaman et al., 2012; Babu \& Devraj, 2008; Almeselmani et al., 2009). The content of biologically active compounds in sprouted seeds can be influenced by various factors such as seed type, genotypic differences, and germination conditions (moisture, temperature, aeration, dark/light, and irrigation solutions).

Oxidative stress is defined as a disturbance in the balance between the production of reactive oxygen species (free radicals) and antioxidant defences. Several studies have suggested that $\mathrm{H}_{2} \mathrm{O}_{2}$ can act as a secondary messenger and control various signalling cascades. Vitamin $\mathrm{C}$ is an important independent antioxidant in protecting cells against death from oxidative stress. The amount of vitamin $\mathrm{C}$ in the unsprouted seeds is very small, but significantly increases during germination.

\section{References}

Almeselmani, M., Deshmukh, P. S., \& Sairam, R. K. (2009). High temperature stress tolerance in wheat genotypes: role of antioxidant defence enzymes. Acta Agronomica Hungarica, 57(1), 1-14. http:// dx.doi.org/10.1556/AAgr.57.2009.1.1.

Asard, H., Smirnoff, J., \& May, N. (2003). Vitamin C: its function and biochemistry in animals and plants. The role of ascorbic acid in defence networks and signalling in plants (Chap. 4, pp. 73-92). Nova York: Garland Science/BIOS Scientific Publishers. 
Ashraf, M., \& Foolad, M. R. (2005). Pre-sowing seed treatment - a shotgum approach to improve germination, plant growth, and crop yield under saline and non - saline conditions. Advances in Agronomy, 88, 223-271. http://dx.doi.org/10.1016/S0065-2113(05)88006-X.

Babu, N. R., \& Devraj, V. R. (2008). High temperature and salt stress response in French bean (Phaseolus vulgaris). Australian Journal of Crop Science, 2(2), 40-48. Retrieved from https://pubag.nal.usda. gov/catalog/2198987

Çakir, Ö., Uçarli, C., Tarhan, Ç., Pekmez, M., \& Turgut-Kara, N. (2019). Nutritional and health benefits of legumes and their distinctive genomic properties. Food Science and Technology (Campinas), 39(1), 1-12. http://dx.doi.org/10.1590/fst.42117.

Cheynier, V., Sarni-Manchado, P., \& Quidean, S. (2012). Recent advances in polyphenol research (Chap. 3, pp. 191-195). Hoboken: Wiley-Blackwell.

Fernandez-Orozco, R., Frias, J., Zielinski, H., Piskula, M. K., Kozlowska, H., \& Vidal-Valverde, C. (2008). Kinetic study of the antioxidant compounds and antioxidant capacity during germination of Vigna radiata cv. Emmerald, Glycine max cv. Jutro and Glycine max cv. Merit. Food Chemistry, 111(3), 622-630. http://dx.doi.org/10.1016/j. foodchem.2008.04.028.

Gharachorloo, M., Tarzi, B. G., Baharinia, M., \& Hemaci, A. H. (2012). Antioxidant activity and phenolic content of germinated lentil (Lens culinaris). Journal of Medicinal Plants Research, 6(30), 4562-4566. Retrieved from http://www.academicjournals.org/JMPR

Graf, B. A., Milbury, P. E., \& Blumberg, J. B. (2005). Flavonols, flavones, flavanones, and human health: Epidemiological evidence. Journal of Medicinal Food, 8(3), 281-290. http://dx.doi.org/10.1089/ jmf.2005.8.281. PMid:16176136.

Hasanuzzaman, M., Hossain, M. A., da Silva, J. A. T., \& Fujita, M. (2012). Plant responses and tolerance to abiotic oxidative stress: antioxidant defenses is a key factors. In V. Bandi, A. K. Shanker, C. Shanker \& M. Mandapaka (Eds.), Crop stress and its management: perspectives and strategies (Chap. 8, pp. 261-316). Berlin: Springer. http://dx.doi.org/10.1007/978-94-007-2220-0_8.

Khayatnezhad, M., Gholamin, R., Jamaati-e-Somarin, S., \& Zabihi-eMahmoodabab, R. (2010). Effects of peg stress on corn cultivars (Zea mays L.) at germination stage. World Applied Sciences Journal, 11(5), 504-506.

Kim, D.-O., Jeong, S. W., \& Lee, C. Y. (2003). Antioxidant capacity of phenolic phytochemicals from various cultivars of plums. Food Chemistry, 81(3), 231-326. http://dx.doi.org/10.1016/S03088146(02)00423-5.

Lim, J. H., Park, K. J., Kim, B. K., Jeong, J. W., \& Kim, H. J. (2012). Effect of salinity on phenolic compounds and carotenoids in buckwheat (Fagopyrum esculentum M.) sprout. Food Chemistry, 135(3), 1065-1070. http://dx.doi.org/10.1016/j.foodchem.2012.05.068. PMid:22953825.

Lithuanian Standards Board - LST. (2000). LST ISO 6557-2:2000: vaisiai, daržoves ir ju gaminiai: askorbo rūgšties kiekio nustatymas: 2dalis: Iprastiniai metodai (pp. 57). Lithuanian: Lietuvos Standartizacijos Departamentas. In Lithuanian.

López-Amorós, M. L., Hernández, T., \& Estrella, I. (2006). Effect of germination on legume phenolic compounds and their antioxidant activity. Journal of Food Composition and Analysis, 19(4), 277-283. http://dx.doi.org/10.1016/j.jfca.2004.06.012.

Mahajan, S., \& Tuteja, N. (2005). Cold, salinity and drought stresses: an overview. Archives of Biochemistry and Biophysics, 444(2), 139158. http://dx.doi.org/10.1016/j.abb.2005.10.018. PMid:16309626.

Mbithi, S., Van Camp, J., Rodriguez, R., \& Huyghebaert, A. (2001). Effects of sprouting on nutrient and antinutrient composition of kidney beans (Phaseolus vulgaris var. Rose coco). European Food Research and Technology, 212(2), 188-191. http://dx.doi.org/10.1007/ s002170000200.

Mendoza-Sánchez, M., Guevara-González, R. G., Castaño-Tostado, E., Mercado-Silva, E. M., Acosta-Gallegos, J. A., Rocha-Guzmán, N. E., \& Reynoso-Camacho, R. (2016). Effect of chemical stress on germination of cv Dalia bean (Phaseolus vularis L.) as an alternative to increase antioxidant and nutraceutical compounds in sprouts. Food Chemistry, 212(1), 128-137. http://dx.doi.org/10.1016/j. foodchem.2016.05.110. PMid:27374516.

Mierziak, J., Kostyn, K., \& Kulma, A. (2014). Flavonoids as important molecules of plant interactions with environment. Molecules (Basel, Switzerland), 19(10), 16240-16265. http://dx.doi.org/10.3390/ molecules191016240. PMid:25310150.

Paśko, P., Bartoń, H., Zagrodzki, P., Gorinstein, S., Fołta, M., \& Zachwieja, Z. (2009). Anthocyanins, total polyphenols and antioxidant activity in amaranth and quinoa seeds and sprouts during their growth. Food Chemistry, 115(3), 994-998. http://dx.doi.org/10.1016/j. foodchem.2009.01.037.

Pérez-Balibrea, S., Moreno, D. A., \& García-Viguera, C. (2008). Influence of light on health - promoting phytochemicals of broccoli sprouts. Journal of the Science of Food and Agriculture, 88(5), 904-910. http:// dx.doi.org/10.1002/jsfa.3169.

Promila, K., \& Kumar, S. (2000). Vigna radiata seed germination under salinity. Biologia Plantarum, 43(3), 423-426. http://dx.doi. org/10.1023/A:1026719100256.

Quan, L. J., Zhang, B., Shi, W.-W., \& Li, H.-Y. (2008). Hydrogen peroxide in plants: a versatile molecule of the reactive oxygen species network. Journal of Integrative Plant Biology, 50(1), 2-18. http://dx.doi. org/10.1111/j.1744-7909.2007.00599.x. PMid:18666947.

Ramakrishna, A., \& Ravishankar, G. A. (2011). Influence of abiotic stress signals on secondary metabolites in plants. Plant Signaling \& Behavior, 6(11), 1720-1731. http://dx.doi.org/10.4161/psb.6.11.17613. PMid:22041989.

Sarvajeet, S. G., \& Narendra, T. (2010). Reactive oxygen species and antioxidant machinery in abiotic stress tolerance in crop plants. Plant Physiology and Biochemistry, 48(12), 909-930. http://dx.doi. org/10.1016/j.plaphy.2010.08.016. PMid:20870416.

Scholz, M., Gatzek, S., Sterling, A., Fiehn, O., \& Selbig, J. (2004). Metabolite fingerprinting: Detecting biological features by independent component analysis. Bioinformatics (Oxford, England), 20(15), 2447-2454. http:// dx.doi.org/10.1093/bioinformatics/bth270. PMid:15087312.

Shah, S. A., Zeb, A., Masood, T., Noreen, N., Abbas, S. J., Samiullah, M., Alim, M. A., \& Muhammad, A. (2011). Effects of sprouting time on biochemical and nutritional qualities of Mungbean varieties. African Journal of Agricultural Research, 6(22), 5091-5098. Retrieved from http://www.academicjournals.org/AJAR

Shetty, K. (2004). Role of proline-linked pentose phosphate pathway in biosynthesis of plant phenolics for functional food and environmental applications: a review. Process Biochemistry, 39(7), 789-804. http:// dx.doi.org/10.1016/S0032-9592(03)00088-8.

Shirley, B. W. (1998). Flavonoids in seeds and grains: physiological function, agronomic importance and the genetics of biosynthesis. Seed Science Research, 8(4), 415-422. http://dx.doi.org/10.1017/ S0960258500004372.

Shulaev, V., Cortes, D., Miller, G., \& Mittler, R. (2008). Metabolomics for plant stress response. Plant Physiology, 132(2), 199-208. http:// dx.doi.org/10.1111/j.1399-3054.2007.01025.x. PMid:18251861.

Silva, E. T., Silva, E., Asquieri, E., Vieira, E., Silva, F., \& Damiani, C. (2018). Physicochemical characterization and behaviour of 
biocompounds of caja-manga fruit (Spondias mombin L.). Food Science and Technology, 38(3), 399-406. Retrieved from http://www.scielo. br/scielo.php?pid=S0101-20612018000300399\&script=sci_arttext

Singleton, V. L., Orthofer, R., \& Lamuela-Raventos, R. M. (1999). Analysis of total phenols and other oxidation substrates and antioxidant by means of folin-ciocalteu reagent. Methods in Enzymology, 299, 152178. http://dx.doi.org/10.1016/S0076-6879(99)99017-1.

Swigonska, S., Amarowicz, R., Król, A., Mostek, A., Badowiec, A., \& Weidner, S. (2014). Influence of abiotic stress during soybean germination followed by recovery the phenolic compounds of radicles and their antioxidant capacity. Acta Societatis Botanicorum Poloniae, 83(3), 209-218. http://dx.doi.org/10.5586/asbp.2014.026.

Tesfay, S. Z., Modi, A. T., \& Mohammed, F. (2016). The effect of temperature in moringa seed phytochemical compounds and carbohydrate mobilization. South African Journal of Botany, 102, 190-196. http://dx.doi.org/10.1016/j.sajb.2015.07.003.

Tripathi, S. S., Mewar, D., Prsad, B., Kumar Jain, V. (2012). Standartization of temperature regimes for better seed germination and seedling growth of Burdock (Arctium lappa). Journal of Hill Agriculture, 3(2), 77-81. Retrieved from http://www.ishaindia.in/JHA/JHA2012Vol3(2).pdf

Urbano, G., Aranda, P., Vílchez, A., Aranda, C., Cabrera, L., Porres, J. M., \& López-Jurado, M. (2005). Effects of germination on the composition and nutritive value of proteins in Pisum sativum L. Food Chemistry, 93(4), 671-679. http://dx.doi.org/10.1016/j.foodchem.2004.10.045.

Vidal-Valverde, C., Frias, J., Sierra, I., Blazquez, I., Lambein, F., \& Kuo, Y. (2002). New functional legume foods by germination: effect on the nutritive value of beans, lentils and peas. European Food
Research and Technology, 215(6), 472-477. http://dx.doi.org/10.1007/ s00217-002-0602-2.

Wróbel, M., Karama, M., Amarowicz, R., Fr czek, E., \& Weidner, S. (2005). Metabolism of phenolic compounds in Vitis riparia seeds during stratification and during germination under optimal and low temperature stress conditions. Acta Physiologiae Plantarum, 27(3), 313-320. http://dx.doi.org/10.1007/s11738-005-0008-4.

Zhishen, J., Mengcheng, T., \& Jianming, W. (1999). The determination of flavonoid contents in mulberry and their scavenging effects on superoxide radicals. Food Chemistry, 64(4), 555-559. http://dx.doi. org/10.1016/S0308-8146(98)00102-2.

Zieliński, H., Frias, J., Piskuła, M. K., Kozłowska, H., \& Vidal-Valverde, C. (2006). Vitamin B1 and B2, dietary fiber and minerals content of Cruciferae sprouts. European Food Research and Technology, 221(12), 78-83. http://dx.doi.org/10.1007/s00217-004-1119-7.

Złotek, U., Szymanowska, U., Baraniak, B., \& Karaś, M. (2015). Antioxidant activity of polyphenols of adzuki bean (vigna angularis) germinated in abiotic stress conditions. Acta Scientiarum Polonorum. Technologia Alimentaria, 14(1), 55-62. http://dx.doi.org/10.17306/J. AFS.2015.1.6. PMid:28068020.

Zróbek-sokolnik, A. (2012). Environmental adaptations and stress tolerance of plants in the era of climate change. In P. Ahmad \& M. N. V. Prasad (Eds.), Temperature stress and responses of plants (Chap. 5, pp. 113-134). New York: Springer.

Чупахина, Г. Н. (1997). Система аскорбиновой кислоты растений (Монография, г4, 120 c). Калининград: СИСТЕМА АСКОРБИНОВОЙ КИСЛОТЫ РАСТЕНИЙ. 